\title{
PEMBELAJARAN TANGGUNG JAWAB DALAM PENJAS DI SEKOLAH
}

\author{
RAJIP MUSTAFILLAH RUSDIYANTO \\ Universitas Majalengka, Majalengka, Jawa Barat, Indonesia \\ rajipmustafillahr@gmail.com
}

\begin{abstract}
ABSTRAK
Artikel ini memuat tentang kajian teoritik upaya meningkatkan perilaku positif di lingkungan siswa sekolah dan remaja. Tujuan dari artikel ini memberikan pengetahuan tentang upaya yang dapat dilakukan untuk menekan kenakalan remaja. Penulis mencoba menjelaskan secara procedural dan sistematis langkah dan tahapan yang digunakan dalam proses pembelajaran tanggungjawab. Dalam prosesnya siswa dituntut untuk saling menghormati dan menjaga perasaan teman, siswa dituntut untuk berpartisipasi dan berupaya dalam segala aktivitas yang ditugaskan, siswa mampu bertanggungjawab pada diri sendiri serta mampu membuat perencanaan hidup sendiri, siswa mampu bekerjasama dengan teman bermaian, dan siswa mampu menerapkan nilai-nilai yang sudah dipelajaran diimplementasikannya dalam kehidupan dimasyarakat.
\end{abstract}

Keyword: Pendidikan Jasmani, Teaching Personal and Social Responsibility, Model Pembelajaran

\section{PENDAHULUAN}

Penjas itu sendiri tertuang dalam kompetensi dasar yang harus dimiliki oleh setiap siswa, serta merupakan bagian dari program-program pendidikan secara umum melalui berbagai aktivitas gerak yang diberikan pada proses pembelajaran yang akan memberikan dampak terhadap pertumbuhan dan perkembangan anak secara menyeluruh (Suherman, 2009, hlm. 19). Penjas menjadi salah satu mata pelajaran wajib di sekolah, maka dari itu pembelajaran penjas haruslah sesuai dengan pengertian pendidikan jasmani menurut Undang-undang Sisdiknas No. 20 Tahun 2003 yang menjelaskan bahwa:

Pendidikan adalah usaha sadar dan terencana untuk mewujudkan suasana belajar dan proses pembelajaran agar peserta didik secara aktif mengembangkan potensi dirinya untuk memiliki kekuatan spiritual keagamaan, pengendalian diri, kepribadian, kecerdasan, akhlak mulia serta keterampilan yang diperlukan dirinya, masyarakat bangsa dan negara. 
Pendidikan jasmani memiliki peranan penting, sebagaimana dijelaskan bahwa "For some people the future for physical education is a future directed towards young people's future health and well-being and, more specifically, their current and future participation in physical activity and sport. (Penney and Jess, 2004). Melalui penjas, masa depan akan mengarahkan pada kesehatan dan kesejahteraan masa depan remaja sebagai pembawa perubahan, serta partisipasi mereka yang berlangsung dan masa depan dalam aktivitas fisik dan olahraga.

Upaya yang sangat mendukung terhadap keterampilan sosial anak "this model was designed by Hellison $(1985,2003)$ as an alternative approach to physical activity programming whose objective is to teach personal and social responsibility to urban youth often placed at risk due to social circumstances such as poverty, violence, drugs and family problems" (Escartí, Gutiérrez, Pascual, and Marín 2010). Model tersebut diterapkan pada proses pembelajaran penjas dalam meningkatkan tanggungjawab sosial bagi remaja yang berada di perkotaan yang memiliki resiko seperti kekerasan, obat-obatan, dan masalah yang dihadapi di lingkungan keluarga.

Upaya penerapan model yang di kembangkan Hellison (2003) yaitu bertujuan untuk meningkatkan perilaku sosial "The nucleus of the TPSR model is that the students, in order to be successful individuals in their social environment, have to learn to be responsible for themselves and with others and to incorporate strategies that allow them to exercise control over their lives" (Escartí, Gutiérrez, Pascual, and Marín 2010).

Hasil penelitian di United States, beberapa sekolah telah mengakui penerapan dan telah berhasil diterapkan di beberapa sekolah sebagai bagian dari program pendidikan jasmani (Oslin, Collier, and Mitchell 2001). Demikian pula dengan penelitian lain, penelitian ini mengungkapkan bahwa TPSR diterapkan di lingkungan belajar hasilnya positif dan memberikan pengaruh terhadap perubahan perilaku siswa (Cutforth and Puckett 1999). Terdapat 26 hasil penelitian "reviewed 26 studies using the TPSR model, and concluded that, though more research was required, there was strong evidence of the theoretical and practical potential of the TPSR as a program for underserved and at-risk youth" (Hellion and Walsh 2002).

Tinggi rendahnya tanggungjawab seseorang merupakan gambaran dari perilakunya di lingkungan masyarakat. "During the twentieth century, the life experiences of adolescents changed substantially. Nowadays they have more access to drugs and are more exposed to electronic media, which bombards them with messages about fashion, money, fame and violence" (Escartí, Gutiérrez, Pascual, and Llopis 2010). Seiring berkembangnya zaman dengan kemajuan teknologi yang pesat dapat memunculkan banyak permasalah jika setiap orang tidak mampu mengontrol dirinya dalam bentuk sikap 
tanggungjawab. Penekanan tentang sikap tanggungjawab perlu diupayakan agar setiap manusia dalam berperilaku dapat dikontrol melalui sikap yang bertanggungjawab.

Berdasarkan definisi sikap tanggungjawab, terdapat beberapa gejala penurunan sikap tanggungjawab yaitu penyalahgunaan obat-obatan (narkoba). Para korban narkoba sebetulnya mengetahui dampak dari obatobatan yang dikonsumsi, berbagai bentuk penyuluhan serta sosialisasi rutin dilakukan oleh berbagai pihak yang mendukung pemberatasan narkoba. Saat ini persoalan ganja masih dominan baik di level nasional dan internasional. Laporan dari UNODC tahun 2016 menunjukkan bahwa 74\% penduduk dunia usia 15-65 tahun mengonsumsi ganja. Sementara itu di Indonesia persentasenya menyentuh angka 44,5\% (Hasil Survey BNN dan Puslitkes UI, 2016). Bahkan dalam kurun waktu 12 tahun terakhir, yaitu 2004 hingga 2016, penyalahgunaan narkotika di Indonesia didominasi oleh jenis ganja. Ini merupakan salah satu contoh penurunan sikap tanggungjawab dalam menjaga kesehatan dirinya sendiri. Tanggungjawab menjadi pondasi yang paling penting dalam kehidupan masing-masing manusia, "self-responsibility is one of the major foundation in the social environment" (McConatha and McConatha 1985). Kasus penyalahgunaan narkoba menjadi suatu masalah yang lebih berat dibandingkan dengan kasus yang berkaitan dengan sikap. Anak remaja sebetulnya memahami betapa buruknya dampak dari penyalahgunaan narkoba, namun kurangnya rasa menyayangi diri sendiri sebagai bentuk dari kurangnya sikap tanggungjawab menjadikan mereka terjerumus dan susah untuk meninggalkan kebiasaan dalam penyalahgunaan narkoba.

Sikap tanggungjawab perlu ditekankan untuk menghindari anak remaja yang memiliki resiko untuk terjerumus dalam lingkungan narkoba, sebagaimana dijelaskan bahwa resiko itu memiliki arti “... definition within this context is the unlikelihood of acquiring the knowledge, skills, and attitudes needed to become successful adults and, specifically, the exhibition of behavior that makes graduation from high school unlikely" (Escartí, Gutiérrez, Pascual, and Marín 2010). Anak remaja dituntut untuk mengubah perilakunya dari perilaku yang menggangu ke sesuatu yang lebih kontruktif. "Working with children to strengthen adaptive skill to face the future has become a relevant topic in today's psychology, and linked to the concept of positive youth development (PYD)" (Escartí, Gutiérrez, Pascual, and Llopis 2010). Hal itu lah yang menjadikan alasan bahwa pengembangan sikap atau tanggungjawab menjadi sangat penting bagi kestabilan lingkungan masyarakat di masa yang akan datang.

Hellison (2003, hal. 8) menjelaskan bahwa "TPSR stands for a set of ideas that have grown out of my attempt to help at risk kids take more 
responsibility for their personal and social development in phisical activity settings". Ungkapan tersebut menjelaskan bahwa TPSR sebagai model dalam membantu siswa untuk lebih bertanggung jawab terhadap dirinya sendiri dan dalam mengembangkan kepribadian sosial dalam konteks pendidikan jasmani. Sebagai mana penjelasan tentang model Hellison oleh Suherman (2009, hal. 90-91) bahwa "melalui model ini guru berharap bahwa siswa berpartisipasi dan menyenangi aktivitas untuk kepentingannya sendiri dan bukannya untuk mendapatkan penghargaan ekstrinsik seperti yang dikembangkan dalam model center". Metzler (2005, hal. 441) mengatakan bahwa: "The main idea behind TPSR is that much of the content taught in physical education programs allows students opportunities to practice and learn how to take responsibility for themselves and others". Gagasan utama di balik model TPSR adalah banyak konten yang diajarkan dalam program pendidikan jasmani memungkinkan siswa memiliki kesempatan untuk berlatih dan belajar bagaimana cara untuk bertanggungjawab untuk diri mereka sendiri dan orang lain. The TPSR model uses physical activity as a vehicle to teach life skills and promote responsible behaviour (Wright and Burton 2008). Penjelasan tersebut memberikan pemahaman tentang model TPSR menggunakan aktivitas fisik sebagai kendaraan untuk mengajarkan siswa terampil dalam kehidupannya serta mempromosikan perilaku yang bertanggungjawab. Suherman (2009, hal. 90) menjelaskan bahwa "model Hellison adalah model pendekatan yang lebih menekankan pada perkembangan individu dan sosial anak didik melalui motivasi instrinsik".

\section{PEMBAHASAN}

1. Skenario Model Teaching Personal and Social Responsibility (TPSR)

Proses belajar mengajar menjadi sangat penting dalam mencapai harapan seorang guru sekaligus tujuan dari kurikulum yang sedang berlaku. Teaching Personal and Social Responsibility (TPSR) merupakan salah satu model pembelajaran dalam konteks perilaku sosial. Menurut Hellison (2003, hal. 41) berlaku lima rencana pengajaran yaitu: 1) counseling time, 2) Awareness talk, 3) Physical activity lesson, 4) group meeting, 5) reflection time. Tujuan dari model TPSR adalah memberikan pengalaman belajar kepada siswa untuk bertanggung jawab untuk mereka sendiri dan cepat tanggap terhadap lingkungannya (Walsh 2008). Terdapat lima tahapan dalam proses belajar mengajar TPSR yaitu relational time (before and after class), Awareness Talk, The Lesson, Group Meeting, dan Reflection Time serta Mentoring Time.

TPSR memberikan pengawasan kepada siswa dalam berperilaku, hal itu dimaksudkan untuk mengontrol perilaku anak. Guru memberikan kesempatan kepada siswa untuk mengontrak perilaku pada tahap review, 
namun sebelumnya siswa harus diberikan informasi tentang rincian kontrak perilaku dalam PBM TPSR, berikut level 0-4 dari TPSR (Hellison, 2003:17):

Level 0: respecting the rights and feeling of others

Level 1: participation and effort

Level 2: self-direction

Level 3: helping others and leadership

Level 4: outside the gym

Kelima level diatas merupakan kontrak perilaku sekaligus tujuan yang harus dicapai oleh siswa dalam setiap aktivitas gerak dalam PBM. Strategi proses pembelajaran yang digunakan oleh Walsh (2008) ada empat fase dalam mengimplementasikan TPSR yaitu:

a. Fase pertama

Tujuan dari fase ini adalah memperkenalkan format TPSR dan strategi dalam menyampaikan berbagai macam program aktivitas gerak. Pada fase ini di focus kan pada level 0 (respect) dan level 1 (effort). Selain itu, pada fase ini bertujuan untuk membentuk hubungan yang dekat dengan siswa itu terlihat dari penjelasan dibawah ini:

Relation time: pada tahap ini yang terpenting adalah membangung kedekatan dengan siswa dengan menyampaikan keunikan dari masingmasing siswa

Awareness talk: pada tahap ini menggambarkan TPSR level 0 respek dan saling menghargai sesama, termasuk dalam mengontrol perilaku siswa didalam proses belajar mengajar. TPSR level 1 siswa dapat menempatkan diri pada kegiatan PBM, untuk selalu mengikuti semua tugas gerak yang diberikan oleh guru.

The Lesson: pada tahap ini guru harus dapat memasukan TPSR level 0 dan 1 kedalam aktivitas gerak. Namun pada fase pertama ini guru memberikan intruksi langsung kepada siswa. pada fase ini guru memberikan foundasi dalam materi ajar.

Group Meeting: pada tahap ini guru memberikan kesempatan kepada siswa untuk mendiskusikan suatu masalah. Guru memerikan suatu pernyataan dengan jawaban setuju atau tidak setuju terhadap satu keputusan disertai alasannya. Pada tahap ini siswa harus mampu menerapkan level 0 (respect) dan level 1 (effort).

Reflection time: pada tahap ini, guru melakukan pembicaraan dengan siswa yang memiliki masalah dengan catatan harian.

b. Fase kedua

Pada fase ini dimulai untuk memperkuat siswa yang lebih yaitu dengan TPSR level 2 (goal setting)- 3 (leadership). Siswa dituntut untuk dapat merencanakan tujuan dari materi ajar yang sedang dipelajari didalam PBM. Siswa juga dituntut untuk terampil dalam memimpin pada saat berlatih. 
Relation time: memfasilitasi hubungan yang lebih dalam secara intensive dari fase ke fase berikutnya. Pada tahap ini guru membantu siswa dalam berlatih dan merencanakan tujuan untuk membuat suasana kelas menjadi harmonis.

Awareness talk: guru mengingatkan kembali tentang perilaku level 0-1. Memberikan pemahaman lebih tentang arti level 2-3 serta hubungan antara level 0-3.

The Lesson: mengintegrasikan level 0-1 kedalam aktivitas gerak melalui pendekatan langsung dan mengintegrasikan level 2-3 kedalam aktivitas (waktu 50\%). Selama pembelajaran guru mencoba menghubungkan sikap tanggungjawab sebagai dasar dalam proses belajar mengajar.

Group Meeting: masing-masing kelompok siswa berdiskusi dengan sikap saling tenggang rasa dalam PBM. Guru memberikan umpan balik terhadap perilaku yang telah mereka perbuat serta menanyakan rencana tujuan dari masing-masing kelompok siswa.

Reflection time: pada tahap ini, guru melakukan pembicaraan dengan siswa yang memiliki masalah dengan catatan harian.

c. Fase ketiga

Tujuan siswa harus mampu mencapai level 3 (self-direction) dan level 4 (caring). Siswa lebih aktif dalam proses pembelajaran. Orientasi pada fase ketiga ini yaitu siswa mampu merencanakan tujuan dia belajar, pekerja keras, berperilaku positif, memiliki perencanaan yang matang.

Relational time: guru terus membina hubungan dengan siswa serta membuat sebuah pembicaraan untuk membahas karir siswa mendiskusikan dan menghubungkan antar siswa.

Awareness talk: mengingatkan kembali level pencapaian 0-4 dan mengimplementasikannya dalam proses belajar. menghubungkan keterkaitan level 0-4. Lebih focus terhadap kerja keras dan membuat perencanaan pembelajaran memiliki keseimbangan diri.

The Lesson: mengintegrasikan level 3-4 kedalam PBM. Guru memberikan waktu lebih kepada siswa untuk mengerjakan rencana pembelajaran dan belajar memimpin.

Group Meeting: masing-masing kelompok siswa berdiskusi dengan sikap saling tenggang rasa dalam PBM. Guru memberikan umpan balik terhadap perilaku yang telah mereka perbuat serta menanyakan rencana tujuan dari masing-masing kelompok siswa.

Uraian diatas menjelaskan bahwa dalam model TPSR lebih menekankan pada social development. Dimana pada setiap fase terselip level tanggungjawab yang harus dilakukan oleh siswa. Jika dibandingkan dengan PBM penjas secara umum, terletak pada kontrak perilaku serta tahapan dari inti pembelajaran. Harapan dari implementasi model TPSR ini dapat 
memberikan perubahan perilaku dari siswa. Ketika siswa menjalin hubungan yang erat dengan seorang guru bisa jadi perubahan perilaku siswa akan berubah, dengan adanya kontrak perilaku bisa mengingatkan siswa dalam mengontrol perilakunya dalam PBM. Outcomes yang akan didapat dari PBM penjas yaitu dapat mengimplementasikan level 0-4 kedalam kehidupan sehari-hari.

\section{Benchmark}

a. TPSR Teacher Benchmark

Table. TPSR teacher Bemchmark

Metzler (2005, hal. 456)

\begin{tabular}{|c|c|}
\hline Benchmark & How to verify \\
\hline $\begin{array}{l}\text { Guru merencanakan rancangan } \\
\text { pembelajaran pendidikan jasmani }\end{array}$ & Memeriksa rancangan pembelajaran \\
\hline $\begin{array}{l}\text { Guru menyadari } \quad \text { dan } \\
\text { mengidentifikasi tingkat masing- } \\
\text { masing siswa dari tanggung jawab }\end{array}$ & $\begin{array}{llr}\text { Guru memiliki catatan } & \text { setiap } \\
\text { perkembangan } & \text { siswa melalui } \\
\text { tingkatan } & & \end{array}$ \\
\hline $\begin{array}{l}\text { Guru mengidentifikasi hal-hal yang } \\
\text { diperlukan dalam kegiatan belajar } \\
\text { TPSR }\end{array}$ & $\begin{array}{l}\text { Guru mengamati siswa dalam } \\
\text { konten aktivitas fisik dan mencatat } \\
\text { perilaku yang menunjukkan kearah } \\
\text { yang diharapkan yang menjadi } \\
\text { acuan level dalam pembelajaran } \\
\text { TPSR }\end{array}$ \\
\hline $\begin{array}{l}\text { Guru menjelaskan kegunaan dari } \\
\text { kegiatan TPSR }\end{array}$ & Mengamati penjelasan guru \\
\hline $\begin{array}{l}\text { Guru menetapkan harapan yang } \\
\text { jelas untuk kegiatan TPSR yang } \\
\text { akan dating }\end{array}$ & ring melakuka \\
\hline $\begin{array}{l}\text { Guru harus memastikan siswa untuk } \\
\text { berpartisipasi dalam pengambilan } \\
\text { keputusan dan proses penetapan } \\
\text { tujuan pembelajaran }\end{array}$ & $\begin{array}{l}\text { 1. Mengamati interaksi guru } \\
\text { dengan siswa } \\
\text { 2. Meminta siswa untuk turut } \\
\text { berpartisipasi dalam aktivitas } \\
\text { fisik }\end{array}$ \\
\hline $\begin{array}{l}\text { Guru melakukan review dan } \\
\text { mengakhiri pembelajaran untuk } \\
\text { membahas perkembangan siswa } \\
\text { mengenai tanggung jawab pribadi } \\
\text { dan social }\end{array}$ & $\begin{array}{l}\text { 1. Guru memeriksa rencana } \\
\text { pelajaran guru } \\
\text { 2. Mengamati dan merekam } \\
\text { interaksi guru dengan siswa dan } \\
\text { mereview pada akhir } \\
\text { pembelajaran }\end{array}$ \\
\hline
\end{tabular}




\section{b. TPSR Student benchmark}

Tabel. TPSR Student Benchmark

Metzler (2005, hal. 457)

\begin{tabular}{|c|c|}
\hline Benchmark & How to verify \\
\hline $\begin{array}{l}\text { Siswa mengetahui level masing- } \\
\text { masing }\end{array}$ & $\begin{array}{l}\text { 1. } \text { Meminta siswa untuk } \\
\text { memberitahu levelnya masing- } \\
\text { masing } \\
\text { 2. } \text { Meminta siswa untuk } \\
\text { memberikan contoh perilaku dan } \\
\text { keputusan dari levelnya masing- } \\
\text { masing }\end{array}$ \\
\hline $\begin{array}{llr}\text { Siswa memahami } & \text { mengapa } \\
\text { kegiatan pembelajaran } & \text { TPSR } \\
\text { dibutuhkan } & & \\
\end{array}$ & $\begin{array}{l}\text { Mengamati siswa pada saat guru } \\
\text { menjelaskan, untuk menentukan } \\
\text { apakah mereka setuju dengan apa } \\
\text { yang guru informasikan }\end{array}$ \\
\hline $\begin{array}{l}\text { Siswa berupaya jujur } \text { dalam } \\
\text { melakukan kegiatan TPSR }\end{array}$ & $\begin{array}{l}\text { Mengamati siswa saat mereka } \\
\text { terlibat dalam aktivitas TPSR dan } \\
\text { perhatikan peristiwa yang } \\
\text { menunjukkan } \\
\text { lakukan }\end{array}$ \\
\hline $\begin{array}{l}\text { Siswa tidak diperkenankan untuk } \\
\text { berperilaku "backslide" (kembali ke } \\
\text { tingkat yang lebih rendah) }\end{array}$ & $\begin{array}{l}\text { Memantau perilaku siswa sesuai } \\
\text { dengan tingkat dan catatan perilaku } \\
\text { yang merupakan indikasi dari } \\
\text { tingkat yang lebih rendah } \\
\text { (kemunduran } \\
\text { diperbolehkan, tetapi tidak boleh } \\
\text { melakukan backsliding secara rutin) }\end{array}$ \\
\hline
\end{tabular}

\section{KESIMPULAN}

Berbagai macam upaya dapat dilakukan dalam memaksimalkan peran penjas untuk mencapai tujuan pendidikan nasional. Upaya tersebut harus sejalan dengan tujuan. Model Teaching Personal and Social Resposibility (TPSR) memberikan gambaran dalam proses pembelajaran yang sejalan dengan tujuan pendidikan nasional. Model ini memberikan sebuah pengalaman belajar, dimana siswa dikontrol oleh sebuah kontrak perilaku yang memberikan pengalaman belajar yang lebih bertanggungjawab. Kesimpulan dari artikel ini adalah, terdapat beberapa aspek yang dapat diperoleh dari hasil pembelajaran tanggungjawab jika diterapkan dalam pendidikan jasmani di sekolah, yaitu; siswa dituntut untuk saling menghormati dan menjaga perasaan teman, siswa dituntut untuk berpartisipasi dan berupaya, siswa mampu bertanggungjawab pada diri 
sendiri serta mampu membuat perencanaan hidup sendiri, siswa mampu bekerjasama dengan teman bermaian, dan siswa mampu menerapkan nilainilai yang sudah dipelajaran diimplementasikannya dalam kehidupan dimasyarakat.

Artikel ini hanya memuat kajian teoritik upaya meningkatkan kesadaran berperilaku dalam menekan perilaku negative yang terjadi dikalangan pelajar dan remaja. Masih perlu tindak lanjut dalam sebuah penelitian yang lengkap sehingga menjadi sebuah keilmuan yang dapat dibuktikan secara eksperimen.

\section{DAFTAR PUSTAKA}

Cutforth, N. and K. Puckett. 1999. "An Investigation into the Organization, Challenges, and Impact of an Urban Apprentice Teacher Program." Urban Review 31(2):153-71.

Dinas Kesehatan Provinsi Jawa Barat. 2016. Profil Kesehatan Tahun 2014. Dinas Kesehatan Provinsi Jawa Barat.

Escartí, Amparo, Melchor Gutiérrez, Carmina Pascual, and Ramón Llopis. 2010. "Implementation of the Personal and Social Responsibility Model to Improve Self-Efficacy during Physical Education Classes for Primary School Children." International Journal of Psychology and Psychological Therapy 10(3):387-402.

Escartí, Amparo, Melchor Gutiérrez, Carmina Pascual, and Diana Marín. 2010. “Application of Hellison's Teaching Personal and Social Responsibility Model in Physical Education to Improve Self-Efficacy for Adolescents at Risk of Dropping-out of School." The Spanish Journal of Psychology 13(2):667.

Hellion, Don and David Walsh. 2002. "Responsibility-Based Youth Programs Evaluation: Investigating the Investigations." Quest 54(4):292-307.

Hellison, Don. (2003). Teaching Personal and Social Responsibility. United States: Human Kinetics.

McConatha, Jasmin Tahmaseb and Douglas McConatha. 1985. "An Instrument to Measure Self-Responsibility for Wellness in Older Adults." Educational Gerontology 11(4-5):295-308.

Metzler, Michael W. 2005. Instructional Models For Physical Education. Arizona: Holcomb Hathaway, inc. 
Oslin, Judy, Connie Collier, and Steve Mitchell. 2001. "Living the Curriculum." Journal of Physical Education, Recreation and Dance 72(5):47-51.

Penney, Dawn and Mike Jess. 2004. "Physical Education and Physically Active Lives: A Lifelong Approach to Curriculum Development." Sport, Education and Society 9(2):269-87.

Suherman, A. (2009). Revitalisasi Pengajaran Dalam Pendidikan Jasmani. Bandung. CV. Bintang WarliArtika.

Walsh, David. 2008. "Helping Youth in Underserved Communities Envision Possible Futures: An Extension of the Teaching Personal and Social Responsibility Model." Research Quarterly for Exercise and Sport 79(2):209-21.

Wright, Paul M. and Suzanne Burton. 2008. "Implementation and Outcomes of a Responsibility-Based Physical Activity Program Integrated Into an Intact High School Physical Education Class." Journal of Teaching in Physical Education 27:138-54. 